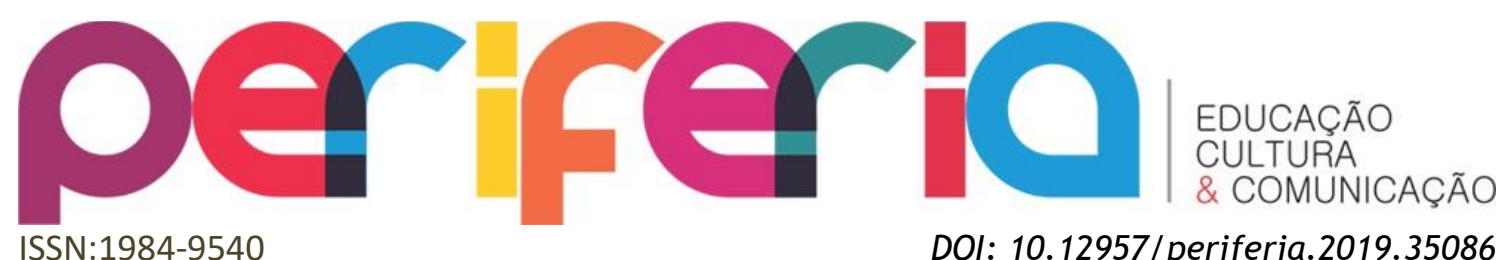

ISSN:1984-9540

DOI: $10.12957 /$ periferia.2019.35086

\title{
EDUCAÇÃO, MEMES E A CATEGORIA TRABALHO
}

\author{
Eddie Francisco Manoel Ferreira Orsini ${ }^{1}$ \\ Secretaria Estadual de Educação do Estado do Rio de Janeiro
}

\section{Resumo}

Neste momento de crise da Educação, em que a realidade da Educação nos Colégios Estaduais da rede regular é extremamente dura, pretende-se investigar o uso de memes e outros elementos gráficos como recurso didático neste ambiente de dificuldades e desafios. Tenta-se construir um modus operandi para o uso da imagem (tão presente na sociedade), mas sem que se perca a riqueza do conteúdo da disciplina. Usa-se a teoria e método de István Mészáros, mas com a presença de outros momentos do marxismo. Neste estudo, o ser humano é compreendido enquanto um complexo de complexos, a saber, trabalho, pensamento e linguagem; mas este axioma lukacsiano é reposicionado pela crítica de Mészáros ao capital e sua sociabilidade caracterizada pela "autoalienação". Desta perspectiva, fica claro que a Educação não deixa de ser a maneira que o indivíduo tem de direcionar sua capacidade de trabalho sobre si mesmo e, claro, também às instituições que fazem parte deste processo. Desta maneira, alcançamos uma aproximação maior entre o universo do educando e o do educador, demonstrando a capacidade dos recursos gráficos como catalisadores do Ensino. No ambiente da pós-modernidade e da revolução informacional com sua fluidez desconcertante, a imagem revelou-se um excelente recurso; mas vimos que ela demanda também que o educador saiba fazer uso dela.

Palavras-chave: Sociologia, Ensino Médio, Crise da Educação, Marxismo, Alienação, Meme.

\footnotetext{
1 Bacharel e Licenciado em Ciências Sociais pelo Instituto de Filosofia e Ciências Sociais da Universidade Federal do Rio de Janeiro. Especialista em Sociologia no Ensino Médio pelo Programa de Residência Docente da Pós-graduação do Colégio Pedro II. E-mail: professorleviata@yahoo.com
} 


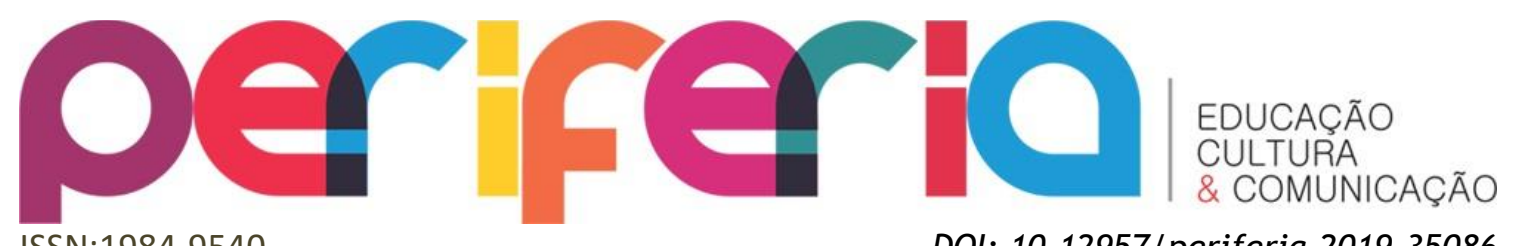

\title{
EDUCATION, MEMES AND THE WORK CATEGORY
}

\begin{abstract}
In this time of Education crisis, in which the reality of education in the State Colleges of regular network is extremely hard intend to investigate the use of memes and other graphics as a teaching resource in this environment of difficulties and challenges. We try to build a modus operandi for the use of the image (as present in society), but without losing the richness of the subject content. It uses the theory and method of István Mészáros, along with the presence of other moments of Marxism. In this study, the human being is understood as a complex of complexes, namely work, thought and speech; but this lukacsian axiom is repositioned by critics of Mészáros to the capital and sociability characterized by "selfalienation". From this perspective it is clear that education is nonetheless the way in which the individual has to direct his ability to work over yourself and of course also the institutions that are part of this process. In this way, we achieve a closer relationship between the universe of the student and of the educator, demonstrating the power of the graphics capabilities as the Education catalysts. In the environment of postmodernity and the information revolution with it is disconcerting fluidity, the image proved to be an excellent resource; but we have seen it demands also that the educator knows how to use it.
\end{abstract}

Keywords: Sociology, High School, Education Crisis, Marxism, Alienation, Meme. 


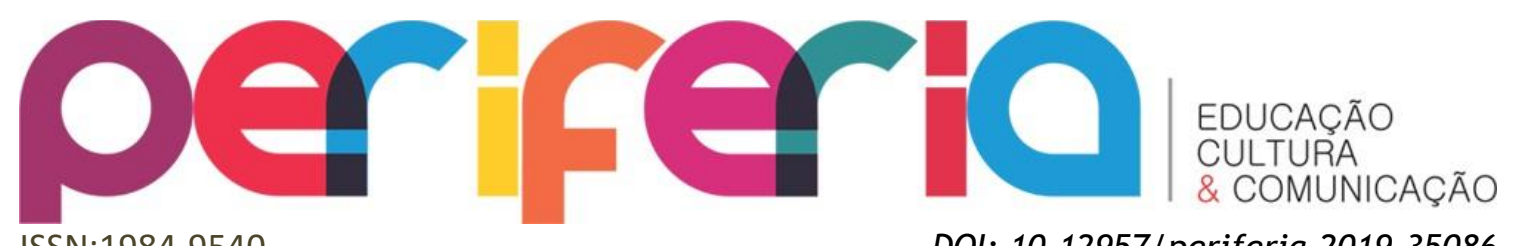

\section{EDUCACIÓN, MEMBRES Y CATEGORÍA TRABAJO}

\section{Resumen}

En este momento de crisis de la Educación, en que la realidad de la Educación en los Colegios Estatales de la red regular es extremadamente dura, se pretende investigar el uso de memes y otros elementos gráficos como recurso didáctico en este ambiente de dificultades y desafíos. Se intenta construir un modus operandi para el uso de la imagen (tan presente en la sociedad), pero sin que se pierda la riqueza del contenido de la disciplina. Se utiliza la teoría y método de István Mészáros, pero con la presencia de otros momentos del marxismo. En este estudio, el ser humano es entendido como un complejo de complejos, a saber, trabajo, pensamiento y lenguaje; pero este axioma lukacsiano es reposicionado por la crítica de Mészáros al capital y su sociabilidad caracterizada por la "autoalienación". De esta perspectiva, queda claro que la Educación no deja de ser la manera que el individuo tiene de dirigir su capacidad de trabajo sobre sí mismo y, claro, también a las instituciones que forman parte de este proceso. De esta manera, alcanzamos una aproximación mayor entre el universo del educando y el de lo educador, demostrando la capacidad de los recursos gráficos como catalizadores de la Enseñanza. En el ambiente de la posmodernidad y de la revolución informacional con su fluidez desconcertante, la imagen se reveló un excelente recurso; pero vimos que ella demanda también que el educador sepa hacer uso de ella.

Palabras clave: Sociología, Enseñanza Media, Crisis de la Educación, Marxismo, Alienación, Meme. 


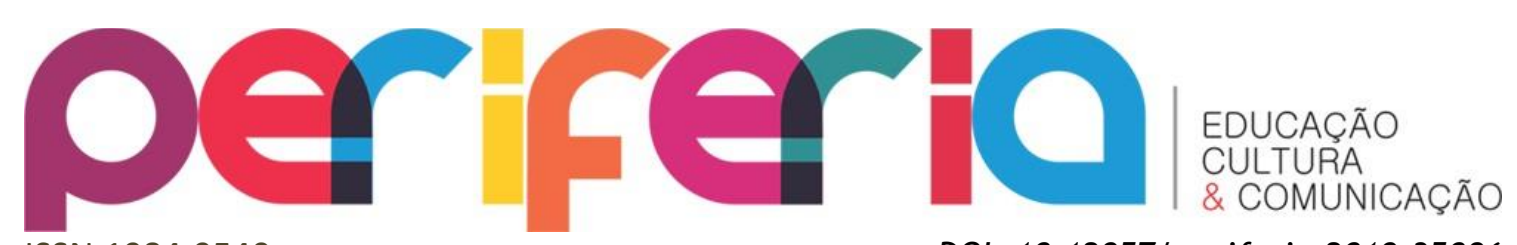

ISSN:1984-9540

DOI: $10.12957 /$ periferia.2019.35086

Introdução

Há muito se fala sobre a crise da Educação e ela é verdadeira. Este artigo não é uma investigação sobre a crise da Educação, ela comparece aqui como realidade efetiva, contudo, mesmo se você discordar do cenário de crise, o artigo pode-the ajudar a ter um método e teoria para trabalhar memes em sala de aula. Neste quadro grave, as imagens podem ser um recurso estratégico na Educação em crise. Mas por quê? Isto ocorre porque há não apenas uma distância entre os educandos e o conhecimento ministrado na Escola que se efetiva na linguagem, mas também nos outros complexos humanos a que Lukács faz referência em suas obras sobre Ontologia, a saber: o trabalho, a linguagem e o pensamento. Logo, tratava-se de construir "uma ponte" entre estes dois universos distantes de complexo de complexos: o do educando e do educador.

Desta maneira, desenvolvemos material didático (em nossa prática docente) com forte e impactante uso de elementos gráficos, com destaque para memes e outros tipos de imagens. Sinalizamos no artigo exemplo de uso de memes em material didático para oferecer exemplos concretos de nossa proposta. Mesmo assim, confirmando a hipótese acima levantada sobre os complexos humanos, vimos que os elementos gráficos são necessários, mas não suficientes; tornam a intervenção do educador ainda mais necessária, e mais produtiva. Memes são recursos gráficos, sobretudo fotos ou imagens animadas que usam uma frase de efeito para exemplificar uma situação social. É dentro desta realidade que os memes - com seu caráter desconcertante e inusitado, cáustico e sarcástico - podem potencializar a aproximação do complexo de complexos do educando e educador.

O objetivo do material didático e da presente reflexão é, por um lado, criar mediações entre o universo do Educando, caracterizado por ter como momento predominante o complexo do trabalho (embora não possa ser dissociado dos dois outros complexos: pensamento e linguagem), e, por outro, igualmente criar mediações entre o universo do educador, escola e todo o legado cultural, cujo momento predominante são o pensamento e a linguagem, que não podem também dissociar-se do terceiro complexo, o trabalho (LESSA, 2006). 

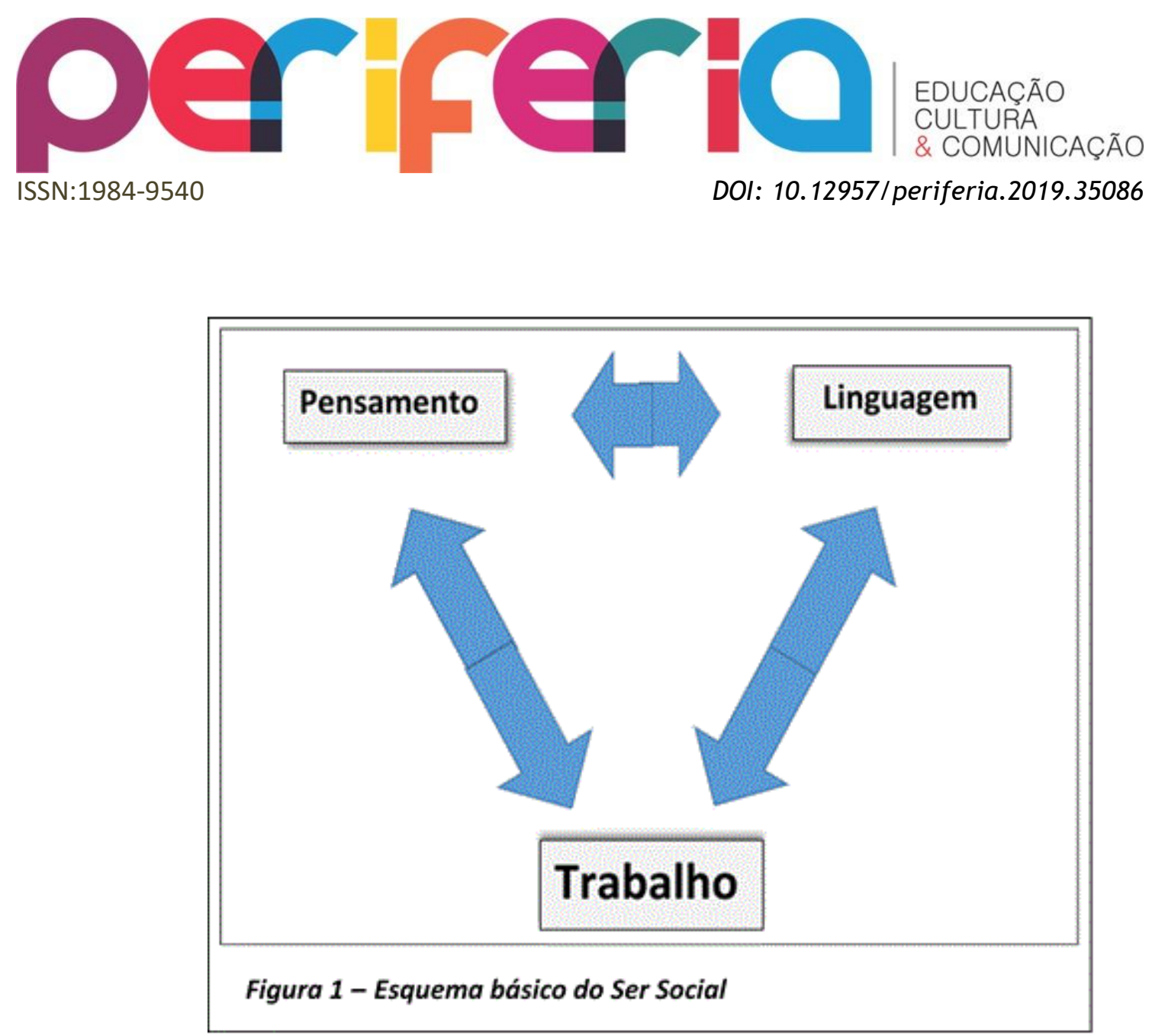

Na sociedade do capital, caracterizada pela divisão do trabalho, temos uma parte dos que trabalham lidando com o saber e o conhecimento humano; mas distante do complexo do trabalho. Doutro lado, temos uma parte desta mesma população lidando com o trabalho, mas distante do pensamento e linguagem. ${ }^{2} \mathrm{Na}$ verdade, mesmo que a sociedade seja estruturada assim, os indivíduos não deixam de ter os três complexos agindo articulada e simultaneamente; mas uma classe se caracteriza por um trabalho aparentemente apenas teórico, e a outra, por um trabalho aparentemente prático; ou trabalho intelectual e trabalho manual.

Todavia, esta unidade que encontramos entre trabalho intelectual e manual (ou do complexo de complexos) é apenas a parte que poderíamos chamar de ontologia positiva do trabalho, pois Marx também caracterizava o trabalho, dentro da sociedade de classes, como uma forma de dominar a classe trabalhadora e a

2 “... os professores partem da hipótese de que existe, entre o ensinante e o ensinado, uma comunidade linguística e de cultura, uma cumplicidade prévia de valores, o que só ocorre quando o sistema escolar está lidando com seus próprios herdeiros" (BOURDIEU, 2002, p. 55-6). 


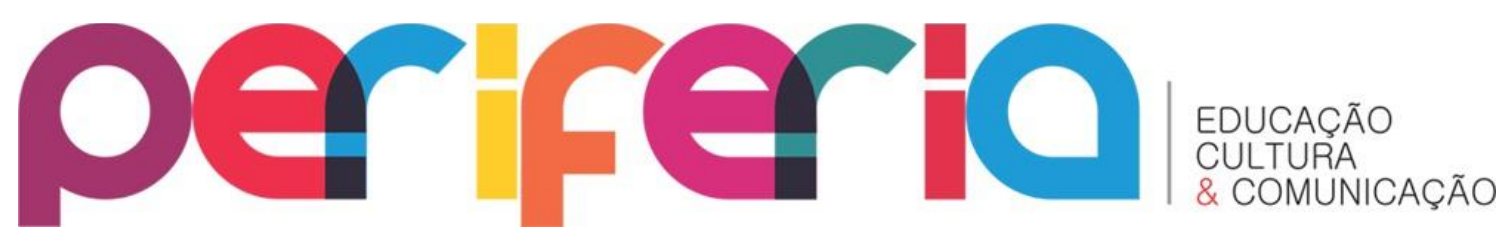

ISSN:1984-9540

DOI: $10.12957 /$ periferia.2019.35086

sociedade por meio das relações do capital. Isto também é confirmado nas propostas marxianas que falam em abolição do trabalho, superação do trabalho, mesmo que somente na fase superior do socialismo: o comunismo. Evidentemente, Marx falava de um projeto real, em que teríamos a transição do trabalho enquanto trabalho alienado, a atividade autoalienada, para o trabalho enquanto autoatividade autônoma dos indivíduos sociais. Porque o trabalho alienado 3 é a principal cadeia com a qual o capital mantém sua subsunção real do trabalho social. Marx pressupõe esta unidade de manual e mental, em seu caráter orgânico, tanto em sentido social como no indivíduo, desde seu primeiro contato com a Economia Política até a sua obra-prima inacabada, $O$ capital.

A vida produtiva é, porém, a vida genérica. É a vida engendradora de vida. No modo da atividade vital encontra-se o caráter inteiro de uma species, seu caráter genérico, e a atividade consciente livre é o caráter genérico do homem. A vida mesmo aparece como meio de vida. 0 animal é imediatamente um com a sua atividade vital. Não se distingue dela. É ela. O homem faz da sua atividade vital mesma um objeto de sua vontade e de sua consciência. Ele tem atividade vital consciente. Esta não é uma determinidade com a qual ele coincide imediatamente. A atividade vital consciente distingue o homem imediatamente da atividade vital animal. Justamente, [e] só por isso, ele é um ser genérico. Ou ele somente é um ser consciente, i. e., a sua própria vida lhe é objeto, precisamente porque é um ser genérico. Eis por que a sua atividade é atividade livre. 0 trabalho estranhado inverte a relação a tal ponto que o homem, precisamente porque é um ser consciente, faz da sua atividade vital, da sua essência, apenas um meio para sua existência. (...)É verdade que também o animal produz. Constrói para si um ninho, habitações, como a abelha, castor, formiga etc. No entanto, produz apenas aquilo de que necessita imediatamente para si ou sua cria; produz unilateral[mente], enquanto o homem produz universal[mente]; o animal produz apenas sob o domínio da carência física imediata, enquanto o homem produz mesmo livre da carência física, e só produz, primeira e verdadeiramente, na [sua] liberdade [com relação] a ela; o animal só produz a si mesmo, enquanto o homem reproduz a natureza inteira; [no animal], o seu produto pertence imediatamente ao seu corpo físico, enquanto o homem se defronta livre[mente] com o seu produto. 0 animal forma apenas segundo a

\footnotetext{
3 "A propriedade privada é, portanto, o produto, o resultado, a consequência necessária do trabalho exteriorizado, da relação externa do trabalhador com a natureza e consigo mesmo. A propriedade privada resulta, portanto, por análise, do conceito de trabalho exteriorizado, isto é, de homem exteriorizado, de trabalho estranhado, de vida estranhada, de homem estranhado" (MARX, 2004, p. 87).
} 


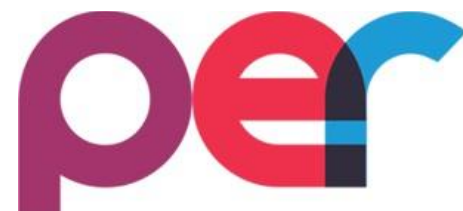

ISSN:1984-9540
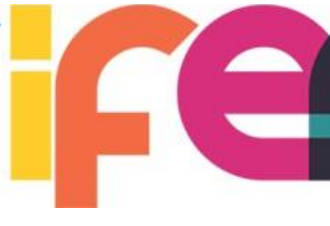

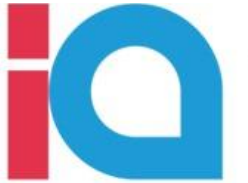

EDUCAÇ̃̃

CULTURA

\& COMUNICAÇÃO

DOI: $10.12957 /$ periferia.2019.35086

medida e a carência da species à qual pertence, enquanto o homem sabe produzir segundo a medida de qualquer specie, e sabe considerar, por toda a parte, a medida inerente ao objeto; o homem também forma, por isso, segundo as leis da beleza. 0 objeto do trabalho é, portanto, a objetivação da vida genérica do homem: quando $o$ homem se duplica não apenas na consciência, intelectual[mente], mas operativa, efetiva[mente], contemplandose, por isso, a si mesmo num mundo criado por ele (MARX, 2004, p. 84-5, grifos nossos).

Por construir, primeiro mentalmente, como teleologia, a sua atividade e produto, o pior arquiteto é melhor que a melhor abelha. Mas as três revoluções industriais interpuseram uma série de mediações da divisão sociotécnica e hierárquica do trabalho entre o cérebro que trabalha e a mão.

Enquanto o processo de trabalho é puramente individual, um único trabalhador exerce todas as funções que mais tarde se dissociam. Ao apropriar-se individualmente de objetos naturais para prover sua vida, é ele quem controla a si mesmo; mais tarde, ficará sob o controle de outrem. O homem isolado não pode atuar sobre a natureza, sem pôr em ação seus músculos sob o controle de seu cérebro. Fisiologicamente, a cabeça e mãos são partes de um sistema; do mesmo modo, o processo de trabalho conjuga o trabalho do cérebro e o das mãos. Mais tarde se separam e acabam por se tornar hostilmente contrários (MARX, 1994, p. 584).

Assim, há um esforço societário em separar o trabalho abstrato dos conhecimentos em geral, e estes do trabalho abstrato - a maioria realiza atividades maquinais e eminentemente práticas e manuais. Por isto também a crise da educação é tão sentida. E mesmo a ciência e o conhecimento, ao primeiro grupo, os que têm o trabalho caracterizado pela predominância do pensamento e linguagem, aparecem mais como instrumentos de trabalho do que como parte deste próprio ser que trabalha com o conhecimento. Doutro lado, dentre os que trabalham distantes do pensamento e linguagem, este trabalho reduzido a trabalho simples e maquinal, encontramos poucas possibilidades de desenvolvimento das suas faculdades em geral. Mas, quanto ao ser social humano, isto não pode ocorrer de maneira absoluta e total, conforme comenta Lukács sobre o desenvolvimento do homem primitivo ao homem civilizado e científico: "com a escolha da pedra inicial começa a ciência" (1969, p. 14).

Baseando-se no trabalho como principal complexo, o educador pode fazer com 


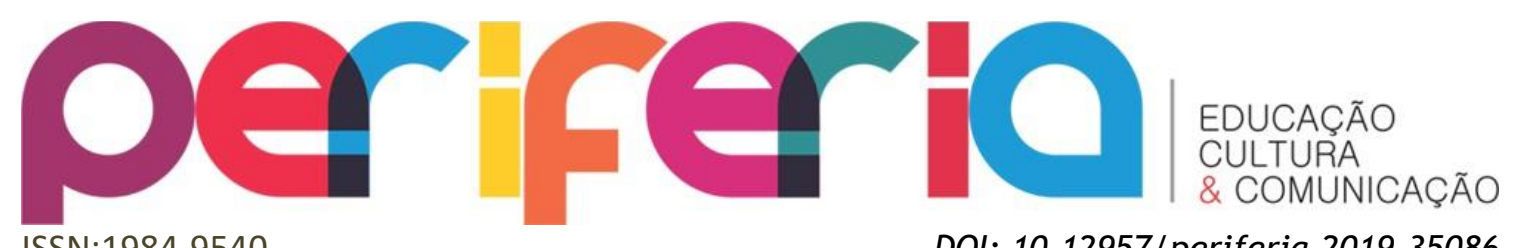

ISSN:1984-9540

DOI: 10.12957/periferia.2019.35086

que o educando tenha uma base material para "incorporar" o capital cultural, por que os universos em questão - dos que vivem do trabalho simples e maquinal e dos que vivem do trabalho intelectual - possui um ponto comum representado pelo material didático e a linguagem e a maneira de pensar do educador. Neste processo, em que o trabalho objetivado em geral é o suporte para as trocas entre os dois universos, podemos ver como a Educação é essencialmente um processo no qual o trabalho é o momento predominante do complexo de complexos:

A acumulação de capital cultural exige uma incorporação que, enquanto pressupõe um trabalho de inculcação e de assimilação, custa tempo que deve ser investido pessoalmente pelo investidor (...). Sendo pessoal, o trabalho de aquisição é um trabalho do 'sujeito' sobre si mesmo (fala-se em 'cultivar-se'). O capital cultural é um ter que se tornou ser, uma propriedade que se fez corpo e tornou-se parte integrante da 'pessoa', um habitus. Aquele que o possui 'pagou com sua própria pessoa' e com aquilo que tem de mais pessoal: seu tempo (BOURDIEU, 2002, p. 74-5, grifos nossos).

A escola não pode deixar de construir-se sobre esta fratura da sociedade do capital, na qual até mesmo o tempo disponível para se cultivar é distribuído de maneira desigual. Devemos, então, fazer uso deste tempo despendido pelo educando em atividades próximas ao universo do trabalho aparentemente apenas manual, ao articular o processo de Ensino-aprendizagem com o capital cultural e social já sedimentado pelo educando.

Quanto a isto há algumas questões ontológicas importantes. 0 trabalho autoalienado causa uma ruptura na mente e no corpo do indivíduo e enseja o pensamento enquanto pensamento ideológico, como tantas vezes Marx e Engels denunciaram. A causação entre ideologia e autoalienação é recíproca, embora a segunda seja o momento originário dos problemas humanos; teríamos uma estrutura existencial como a retratada na figura 2. 

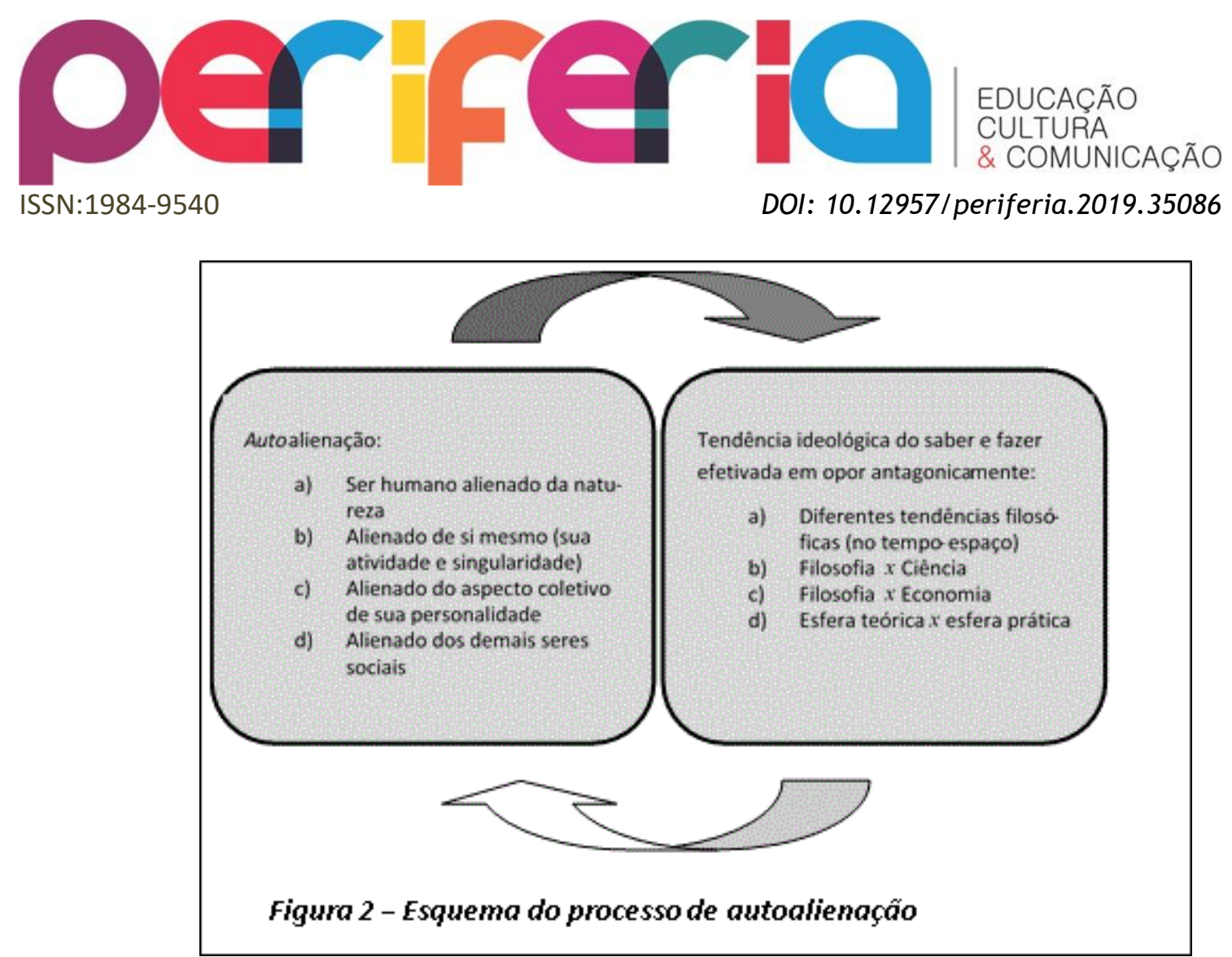

Tendo como pressupostos ontológicos o pensamento marxiano, buscamos entender o que conta para o processo de Ensino-aprendizagem. 0 trabalho objetivado em qualquer maneira - do educando e do educador - é que revela até onde pode ir a capacidade, e apenas o que foi objetivado pelo indivíduo é o que conta para seu aprimoramento, pois "Ninguém vê o que está oculto nele [no ser humano], mas apenas o que suas obras revelam" (Paracelso apud Mészáros, 2006a, p. 267).

Logo, o trabalho objetivado é o suporte necessário para a troca de informações entre educador e educando. E é através deste processo que o educando e o educador vão realizando descobertas, tanto no sentido de que o que não sei não deixa de ser uma descoberta e passo a conhecer ou descubro por dedução/indução; não deixa de ser também uma descoberta (mesmo que o processo tenha sido feito); mas igualmente, antes deste processo de descoberta, para educador e educando, estas coisas descobertas simplesmente não existem em suas consciências. Temos, então, que levar estas questões ontológicas em consideração no desenvolvimento do processo pedagógico. Assim, ambos os lados do processo pedagógico - educador e educando - vão ampliando seus círculos de conhecimento com estes tipos diferentes de descobertas. 


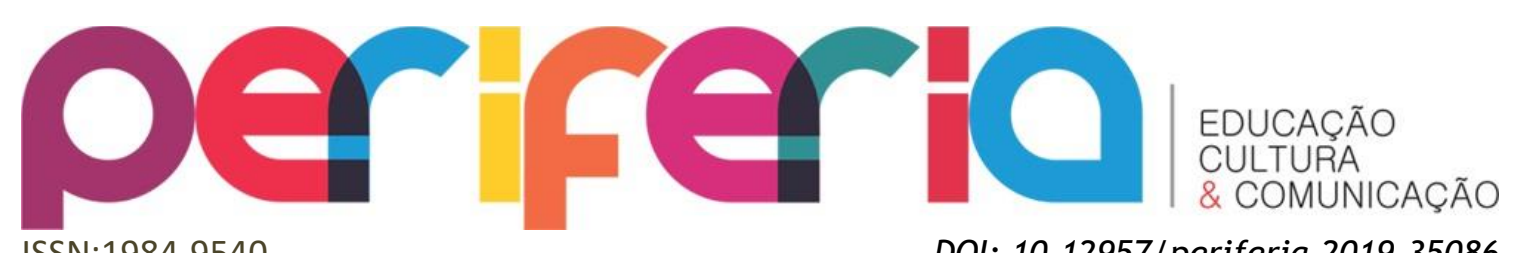

ISSN:1984-9540

DOI: 10.12957/periferia.2019.35086

Outro fator ontológico que dificulta a educação atualmente é o fato de que tanto o que é falado, trabalhado, pensado dos dois lados (educador e educandos), só pode ser compreendido até onde vão os sentidos de ambos; por isto, o trabalho do educador deve estar articulado com o pensamento e a linguagem de ambos os lados. Comenta Marx:

Assim como para o ouvido não musical a mais bela música não tem nenhum sentido, é nenhum objeto, porque o meu sentido só pode ser a confirmação de uma das minhas forças essenciais, portanto só pode ser para mim da maneira como a minha força essencial é para si como capacidade subjetiva, porque o sentido de um objeto para mim (...) vai precisamente tão longe quanto vai o meu sentido...; [é] apenas pela riqueza objetivamente desdobrada da essência humana que a riqueza da sensibilidade humana subjetiva... (2004, p. 110).

Temos que considerar estes três aspectos: o que foi objetivado como obra de ambos os lados, as descobertas feitas e os sentidos teoréticos do educador e educando. Do contrário, teremos apenas o difícil diálogo que vemos atualmente entre educadores e educandos, característico da crise da Educação.

As imagens e os memes são muito produtivos também porque a cultura contemporânea é marcada pela predominância da imagem e sua força e capacidade de comunicação. Isto não significa ficar preso ou limitado à imagem - ela é apenas um convite para que educador e educandos mergulhem no universo letrado sem esquecer o mundo. Quando a imagem está articulada ao conteúdo disciplinar, temos, muitas vezes, uma situação concreta retratada, com a qual o educando pode associar o conteúdo com sua realidade, conhecendo-a, e também à Sociologia. 0 que deve ficar patente é que a maior parte do capital cultural de uma pessoa não está associado diretamente à escola. Assim sendo, devemos criar estratégias para que se aproveite o conhecimento já sedimentado e construam-se veículos entre o tempo que o educando despende na educação formal e a totalidade do aprendido, no tempo livre e tempo de trabalho.

Desta maneira, pensamos realizar a mediação necessária entre o universo do educador e dos educandos, para que possa ser realizado o processo de cultivação do corpo e do espírito. Outro aspecto importante é que, de um lado, o universo do educando, geralmente, está associado a uma cultura mais marcada pela oralidade; 


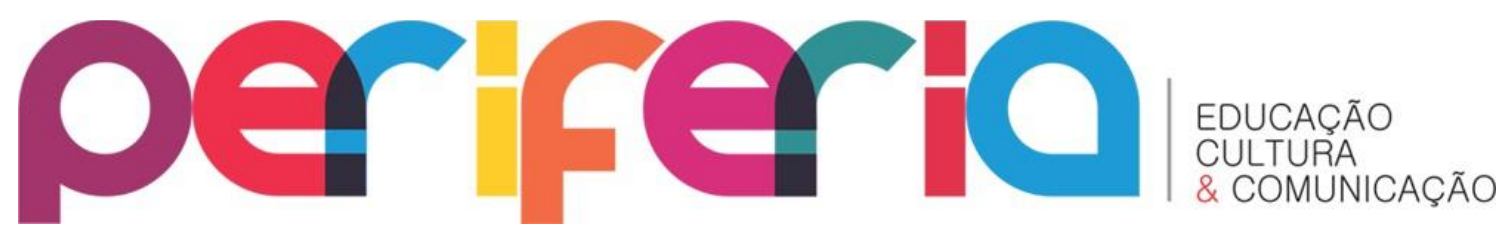

ISSN:1984-9540

DOI: $10.12957 /$ periferia.2019.35086

do outro lado, no universo em que o educador e o conhecimento estão inseridos, a forma escrita é que tem o predomínio. A imagem e os recursos gráficos em geral podem fazer com que este universo predominantemente determinado pela forma escrita se torne menos abstrato e codificado, aproximando-se do universo existencial do educando no qual a forma oral e menos abstrata é o momento mais importante. O meme, por seu apelo popular, franqueia ainda mais o caminho entre a cultura letrada e o universo cujo momento predominante é a oralidade. 0 cartoon, o meme e demais recursos gráficos fazem a intervenção do educador ainda mais necessária, mas também mais produtiva e próxima do educando sem deixar de realizar o trânsito para a forma escrita, que é o cerne da Educação. E a capacidade da imagem de fomentar as emoções é muito recompensadora para o Ensino-aprendizagem, pois as ocasiões mais marcantes são as em que a emotividade do prazer e desprazer reforça a memória.

Uma consideração é importante sobre a leitura e o universo simbólico.

exercício [ou seja, trabalho] necessário e permanente de estabelecer relações entre o texto e o contexto. [...] eu digo que ler não é só caminhar sobre as palavras, e também não é voar sobre as palavras. Ler é reescrever o que estamos lendo. É descobrir a conexão entre o texto e o contexto do texto, e também como vincular o texto/contexto com o meu contexto, o contexto do leitor [vinculálo também a uma escrita que nascerá daqui, do que é o ser social, "indivíduo social", os seus sentidos]. E o que acontece é que muitas vezes lemos autores que morreram cem anos atrás e não sabemos nada sobre nossa própria época! Portanto, sou favorável a que se exija seriedade intelectual para conhecer o texto e o contexto. Mas, para mim, o que é importante, o que é indispensável, é ser crítico. A crítica cria a disciplina intelectual necessária, fazendo perguntas ao que se lê, ao que se está escrito, ao livro, ao texto. Não devemos nos submeter ao texto, ser submissos diante do texto. A questão é brigar com o texto, apesar de amá-lo, não é? Entrar em conflito com o texto. Em última análise, é uma operação que exige muito. Assim, a questão não é só impor aos alunos numerosos capítulos de livros, mas exigir que os alunos enfrentem o texto seriamente (FREIRE apud MOTA, 2003, p. 99-100, Grifos nossos).

Uma vez que estabelecemos nossos objetivos, visamos agora - escolhido o uso dos recursos gráficos - demonstrar por que motivo justificamos nossa escolha baseando-nos em três conceitos básicos da Teoria Marxista, a saber: a alienação, a ideologia e a sociedade do espetáculo. 


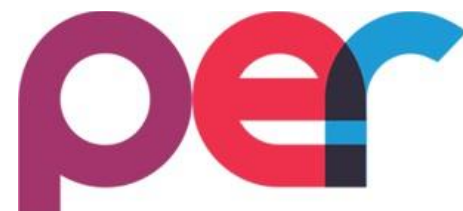

ISSN:1984-9540

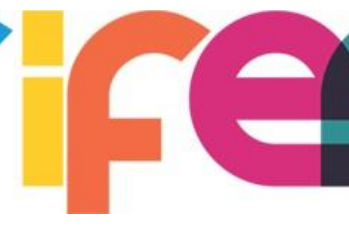

O presente da sociedade é caracterizado por esta autoalienação e o complexo ideológico que emerge da autoalienação, mas também é caracterizado o que Guy Debord chamou de sociedade do espetáculo:

Toda a vida das sociedades nas quais reinam as modernas condições de produção se apresenta como uma imensa acumulação de espetáculos. Tudo o que era vivido diretamente tornou-se uma representação (...) O espetáculo não é um conjunto de imagens, mas uma relação social entre pessoas, mediada por imagens. (...) Considerado em sua totalidade, o espetáculo é ao mesmo tempo o resultado e o projeto do modo de produção existente. Não é um suplemento do mundo real, uma decoração que the é acrescentada. É o âmago do irrealismo da sociedade real. Sob todas as suas formas particulares (...) O espetáculo domina os homens vivos quando a economia já os dominou totalmente. 0 espetáculo é o capital em tal grau de acumulação que se torna a imagem (DEBORD, 2011, p. 1325).

O universo do espetáculo, e não apenas a mídia, acaba por fazer com que as pessoas acreditem mais na imagem do espetáculo do que na própria realidade cinzenta. 0 que é vendido através da imagem é uma coisa totalmente diferente da realidade. Neste exemplo, a imagem descreve a teoria de Debord com a própria realidade por meio da fotografia.

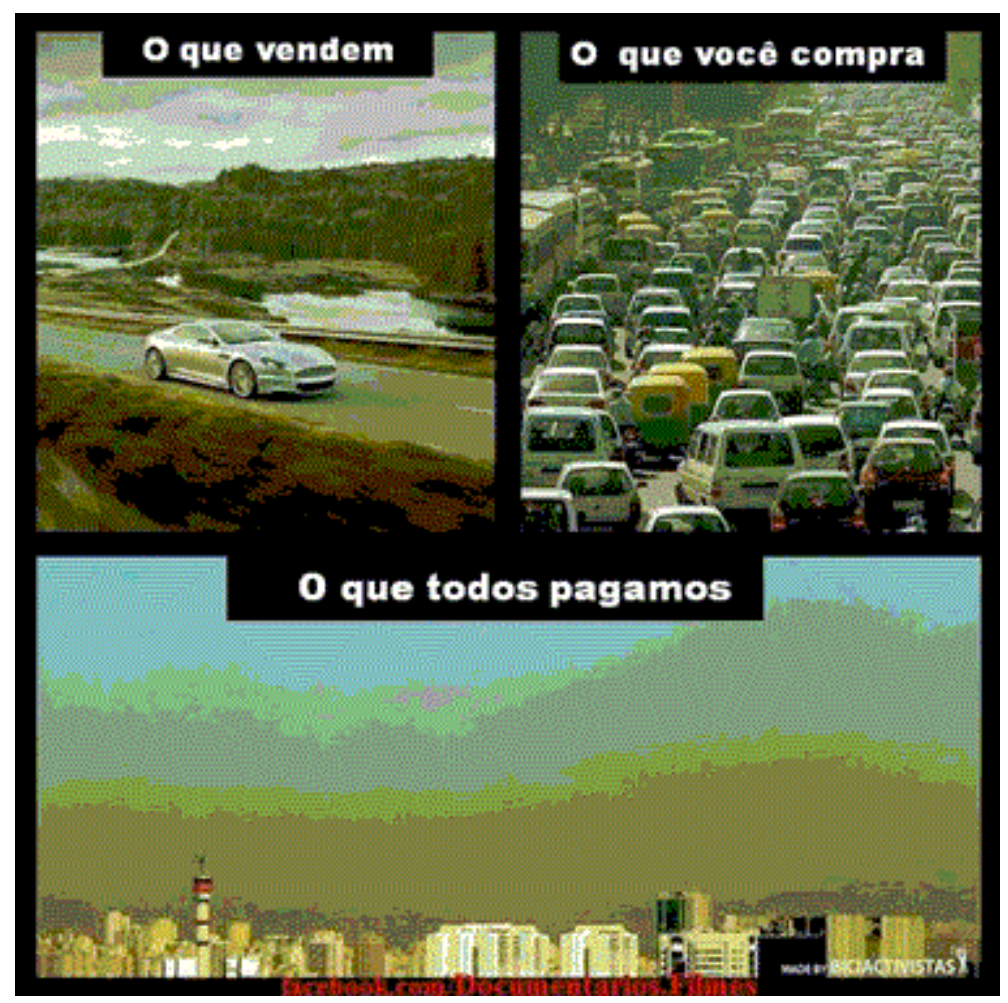

Periferia, v. 11, n. 2, p. 291-316, maio/ago. 2019 


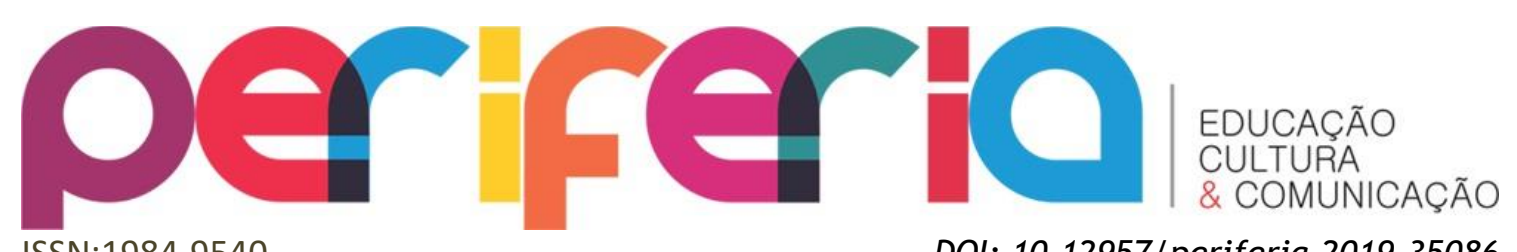

ISSN:1984-9540

DOI: 10.12957/periferia.2019.35086

Inversamente, o conteúdo de Sociologia, e não apenas o marxista, não se prende a aparência e a imagens superficiais, indo a fundo na essência da sociedade. O que significa não apenas uma ideia distante do que há para a maior parte da população da sociedade do capital na era da sociedade do espetáculo e, na verdade, uma ideia inversa a estas ideias com as quais o educando tem contato.

Como a alienação não é algo homogêneo, devemos retomar o debate de Marx - para Feuerbach, a alienação é uma totalidade homogênea, produzindo apenas "consciência alienada". Mas "não devemos partir da suposição, autodestrutiva, de que a alienação é uma totalidade inerte e homogênea. [Assim feito] (...) a única coisa que podemos opor a esse pesadelo conceitual é um conceito igualmente assustador de 'movimento' e 'negação' como 'nulidade'. (...) Surge da suposição de opostos dualistas abstratos e rígidos - como a 'necessidade absoluta' e a 'liberdade absoluta' - que, por sua própria definição, não podem comunicar-se e interagir um com o outro. Não há nenhuma possibilidade genuína de movimento num retrato como este da realidade" (MÉSZÁROS, 2006a, p. 165). Estes opostos dualistas não existem, não enquanto totalidades inertes e homogêneas, e tanto a sociedade do capital como as imagens produzidas por pessoas, cuja vida se passa nesta sociedade, não são, portanto, apenas dados de uma "consciência alienada". Cabe partir das imagens e ideias que a sociedade já produziu e pelos quais a "consciência da alienação" já se faz ativa - acionando o instrumental da Sociologia -, de maneira que até mesmo a imagem e a ideia que mais represente a "consciência alienada" não se torna antididática ou antipedagógica; pois o educador possui a chave heurística que permite a ele e ao educando extraírem conhecimento dela.

$E$ a sociedade do espetáculo se torna tão importante que consome recursos que deveriam ser destinados a outras áreas. Celebridades passam a ter mais apelo para a opinião pública que outros segmentos; mesmo os intelectuais. A sociedade do espetáculo domina a mente das massas, fazendo com que, mesmo com necessidades básicas não atendidas, logo a classe dominante consiga seus sucessos políticos na minguante democracia. 


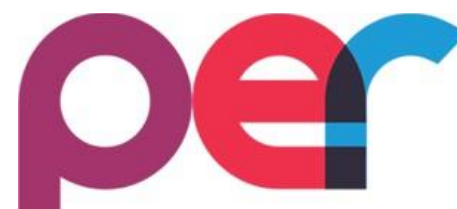

ISSN:1984-9540
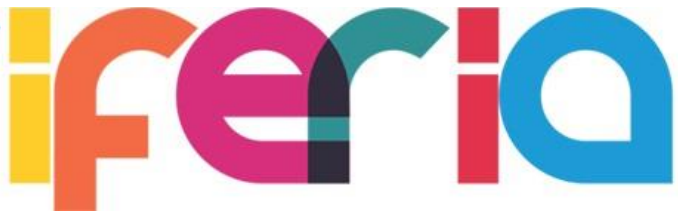

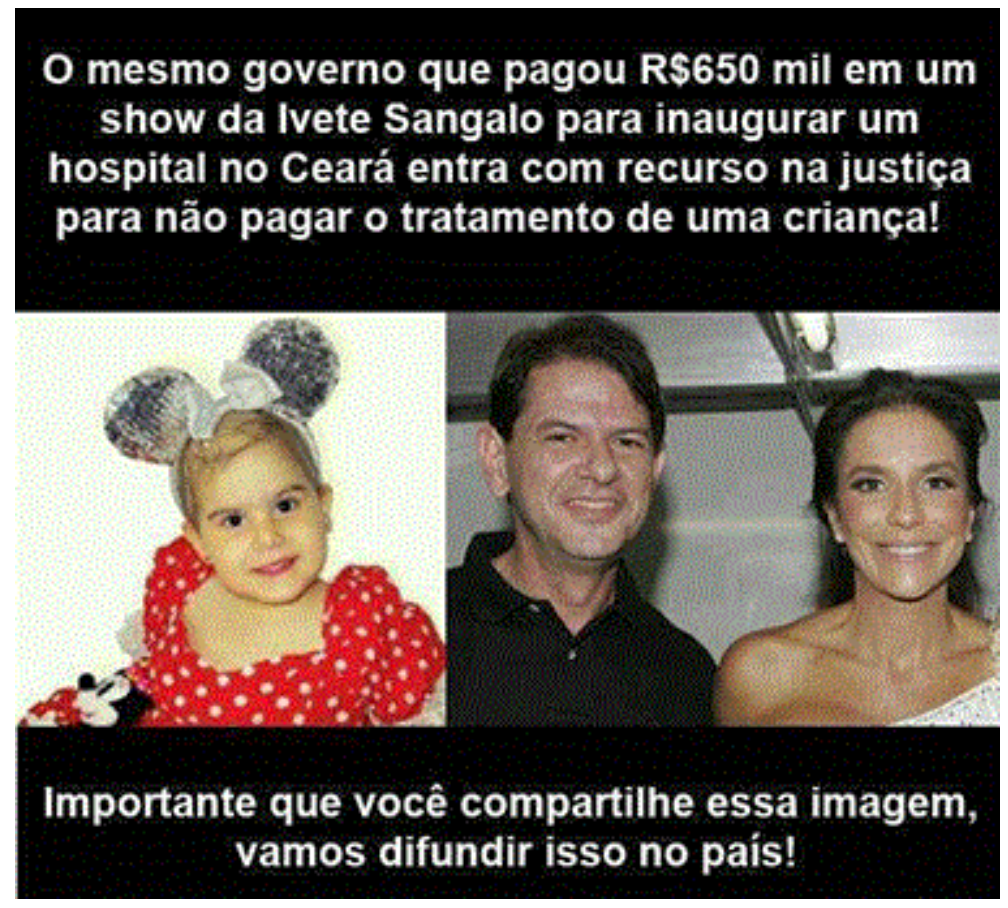

Logo,

A formação dos cinco sentidos é um trabalho de toda a história do mundo até aqui. 0 sentido constrangido à carência prática rude também tem apenas um sentido tacanho. (...) O homem carente, cheio de preocupações, não tem nenhum sentido para o mais belo espetáculo; o comerciante de minerais vê apenas o valor mercantil, mas não a beleza e a natureza peculiar do mineral; ele não tem sentido mineralógico algum; portanto, na objetivação da essência humana, tanto do ponto de vista teórico quanto prático, é necessária tanto para fazer humanos os sentidos do homem quanto para criar sentido humano correspondente à riqueza inteira do ser humano e natural (MARX, 2004, p. 110-111).

Desta forma, a imagem, o espetáculo e o meme são usados enquanto catalisadores do processo de Educação dos sentidos humanos; pois são eles os meios para que a apreensão do conhecimento; Bourdieu comenta que o capital cultural tende a retornar ao corpo que já o tem incorporado (2011, p. 304-307). Podemos, então, usar a imagem e estes recursos didáticos para que os educandos que possuem maior capital cultural incorporado possam ajudar, elevando a zona de 


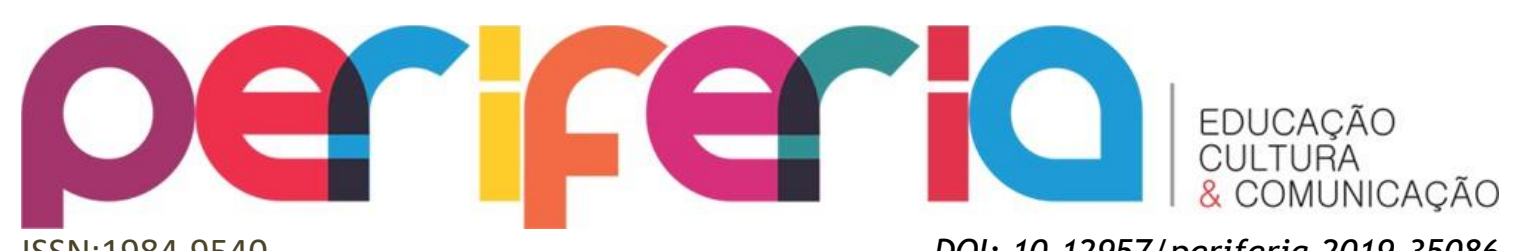

ISSN:1984-9540

DOI: $10.12957 /$ periferia.2019.35086

desenvolvimento proximal ao ter um ponto comum entre toda a turma e o educador, representado neste elemento gráfico. Outro aspecto fundamental é que estes elementos gráficos são mobilizadores de uma série imensa de sentimentos cuja importância a Pedagogia não nega, como podemos ver no truísmo que afirma que lembramos as coisas que mais nos desagradam e mais nos agradam; logo, tocados pela imagem e os sentimentos que ela representa, encontramos melhores condições para a sedimentação do conteúdo disciplinar. Desta maneira, a confusão antes instaurada pela tumultuada relação de "consciência alienada" e "consciência da alienação" na qual o educando se encontra, pode ser superada pelo uso do capital cultural da Sociologia, garantido pela criação de uma comunidade de sentidos, construídos por serem partilhados a mesma linguagem, o mesmo pensamento e o mesmo trabalho. Evita-se assim a unilateralidade de achar que a imagem e o espetáculo não podem ser humanos, "consciência da alienação"; não são apenas monopólio do capital.

Além disto, o meme e os elementos gráficos possuem outra grande vantagem: seu poder de síntese dos componentes sociais mais complexos e das ideias mais sofisticadas. Claro, não se trata de acreditar no absurdo de que uma imagem vale mais que mil palavras, talvez mesmo uma pessoa não tão instruída possa já demonstrar como mil palavras podem fazer muito mais que uma imagem... Trata-se, sim, de ver que as mil palavras serão muito mais significativas ao possuírem como suporte um elemento gráfico que não apenas exemplifique, mas mostre a relação complexa que há na realidade cuja existência é uma mônada na qual os mais diferentes conceitos estão presentes, mesmo que em um pedaço pequeno da realidade, podendo ser representados por uma rede conceitual, na qual poderemos ver também a interdisciplinaridade demandada pela compreensão desta mesma realidade social.

Por fim, como, nos últimos anos, a sociedade do capital foi não apenas tomada pela produção espetacular, mas igualmente por modismos conceituais da pósmodernidade e, sobretudo, pela realidade fragmentária que a pós-modernidade da acumulação flexível exerce sobre nossas existências e consciências, o educando terá 


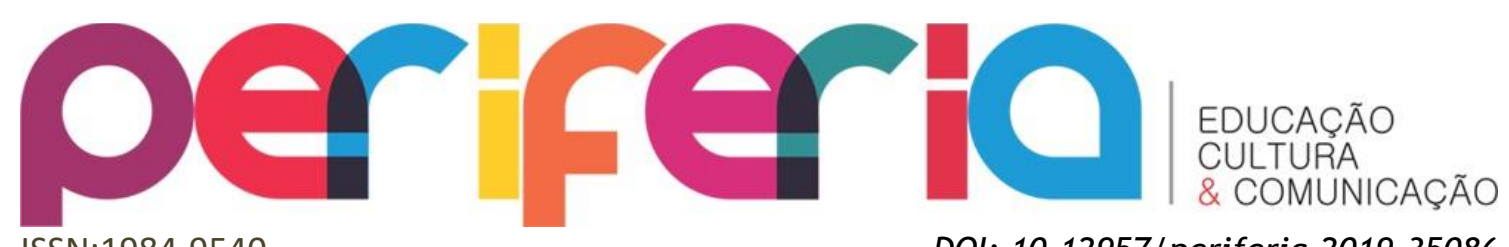

ISSN:1984-9540

DOI: 10.12957/periferia.2019.35086

acesso a um conhecimento que pode fazer com que ele enxergue mais do que a aparência superficial que estes elementos nos apresentam no dia a dia, devido à narrativa hegemônica fragmentadora.

Vimos anteriormente que o ato de ler não é uma questão pouco complexa; ler, na verdade, é reescrever o que se está lendo; dentro das condições normais, o indivíduo que lê não aceita irrestritamente o texto e pode até brigar com ele. Assim, o suporte gráfico cumpre um papel fundamental porque, embora escrito, dentro do universo letrado, muitas vezes ele fala fluentemente a linguagem comum oral do cotidiano e pode oferecer a mediação procurada para que o conteúdo de Sociologia, na maioria das vezes sumamente erudito, torne-se mais próximo à existência do educando, sem que ele deixe de ter um gosto do universo letrado do qual a maioria da população está tão distante, como vemos nas pesquisas que comprovam os números modestos de leitores no país.

O fetichismo acaba sendo tão dominante que aceitamos coisas que são erradas não apenas moralmente, mas até economicamente. 0 que é aceito ou não aceito é condicionado também pela sociedade do espetáculo e a autoalienação cotidiana da práxis. Isto não se trata de uma questão moral, mas de uma questão ontológica com estes critérios - como ser feliz? Não seria também difícil associar este post à situação de anomia que Durkheim estuda, à questão do suicídio.

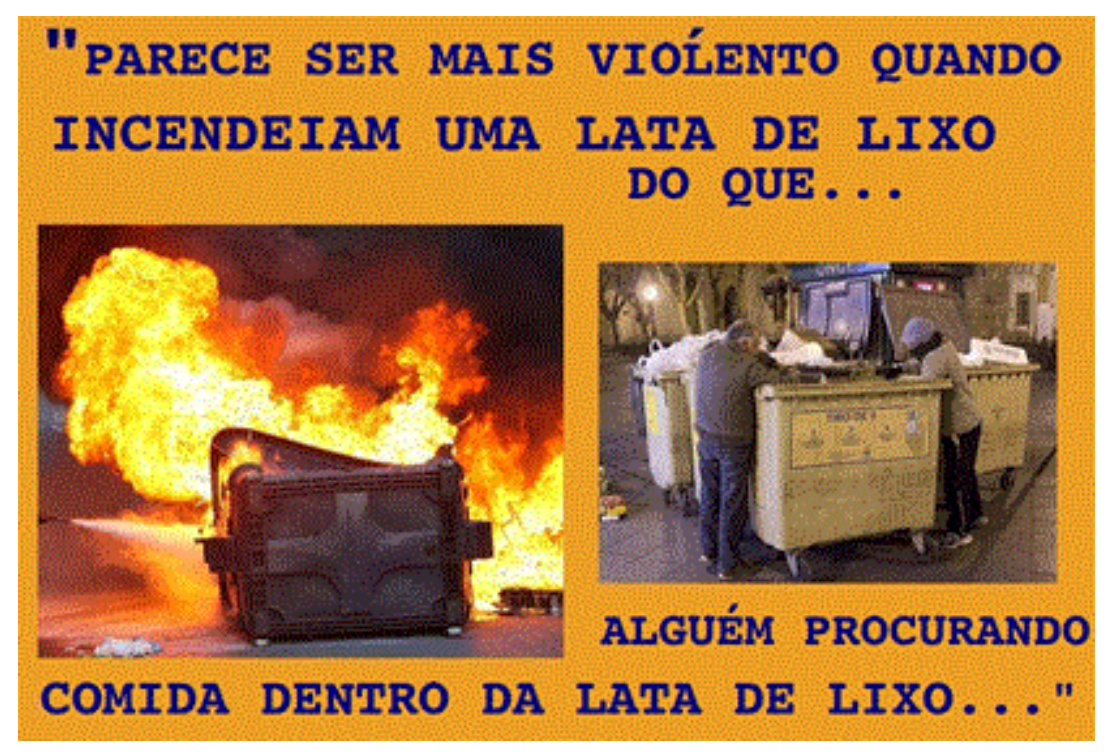

Periferia, v. 11, n. 2, p. 291-316, maio/ago. 2019 


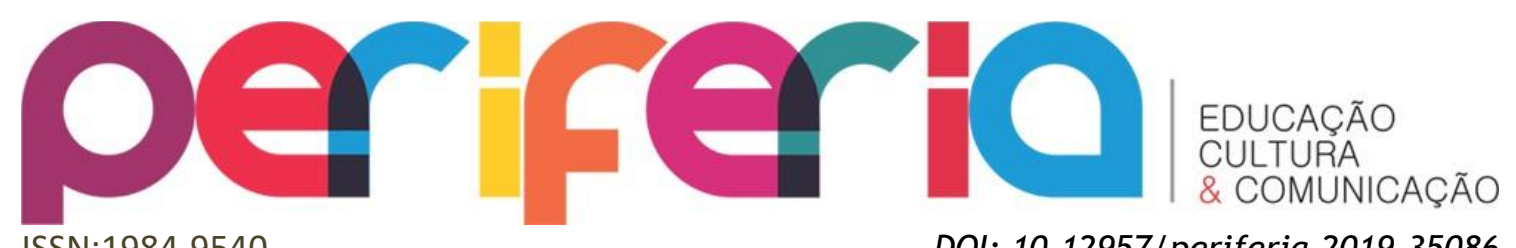

ISSN:1984-9540

DOI: 10.12957/periferia.2019.35086

Inverte-se, desta maneira, a tendência à alienação a que a sociedade do espetáculo joga a população tornando o Ensino-aprendizagem da Sociologia dificultado pelo simulacro que o espetáculo oferece - no lugar da coisa em si -, tratando de tornar nossos sentidos estranhos à reflexão crítica. Estas são as grandes linhas teóricas quanto ao uso de memes nas aulas de Sociologia (ou mesmo outras matérias), devemos, agora, pensar metodologicamente a questão do uso da cibercultura e outros elementos gráficos na Educação.

Devemos diferenciar Metodologia de técnicas de pesquisa. Independente da técnica de pesquisa (métodos qualitativos ou quantitativos, ou qualquer outra abordagem), a grande questão que está em jogo é o controle semântico, o controle do sentido - por isto, uma visão do todo é essencial, contudo, não suficiente. Tratase da diferença entre o que poderíamos chamar de lógica e do que é conhecido como dialética. Uma realidade social só pode ter todos os seus sentidos apreendidos quando, além de esgotadas as possibilidades lógicas, deve-se considerar não apenas a ideia oposta e contrária; a ambiguidade e, até mesmo, a polissemia inerente ao ser humano; como também considerar que há a possibilidade criadora, isto é, automediadora também inerente às pessoas e à sociedade. Esta é a dimensão dialética; diferente da dimensão lógica. Mas o capital com sua maneira de se efetivar, que nos faz tender ao dualismo e cair em dicotomias, compromete a apreensão do sentido da ação social. Comenta Mészáros:

De fato, o mesmo tipo de dicotomias a-dialéticas, característico do sistema do capital como um todo, teve de prevalecer por meio da dominação da quantidade sobre a qualidade, do abstrato sobre concreto, e do formal sobre o substantivo, da maneira como vimos no domínio necessariamente reificador do valor de troca sobre o valor de uso sob a relação universal de valor de ordem reprodutiva estabelecida (2011, p. 175).

Estas inversões que ocorrem, quando quantidade, abstrato e formal tornam-se a maneira de operar do capital, tanto são produto desta forma de conhecimento baseada na lógica e demonstrando desprezo pela dialética, como também tal forma 


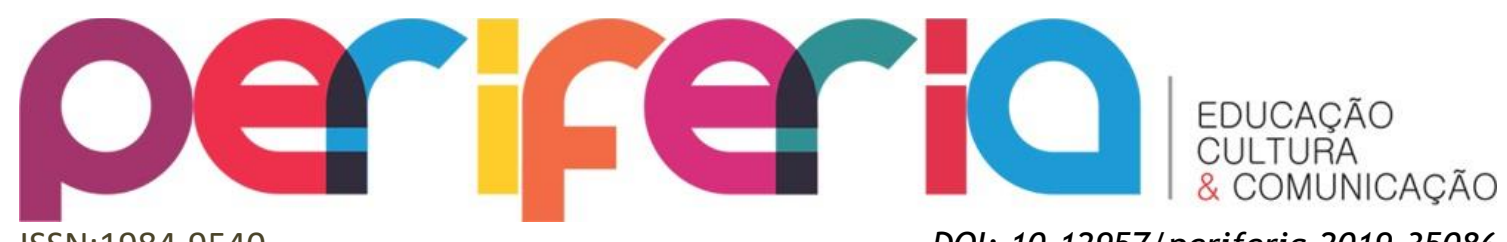

ISSN:1984-9540

DOI: 10.12957/periferia.2019.35086

histórica de conhecimento é produtora das estruturas e limites do capital. Forma-se, então, um verdadeiro ciclo vicioso; contudo, como vimos na parte em que estabelecemos que a alienação não pode ser homogênea, isto também significa que este ciclo pode ser quebrado. Nossa postura metodológica, desta maneira, constituise em buscarmos a mediação cujo desdobramento conduz para fora do ciclo vicioso. Então, devemos realizar também a totalização dialética do objeto de pesquisa.
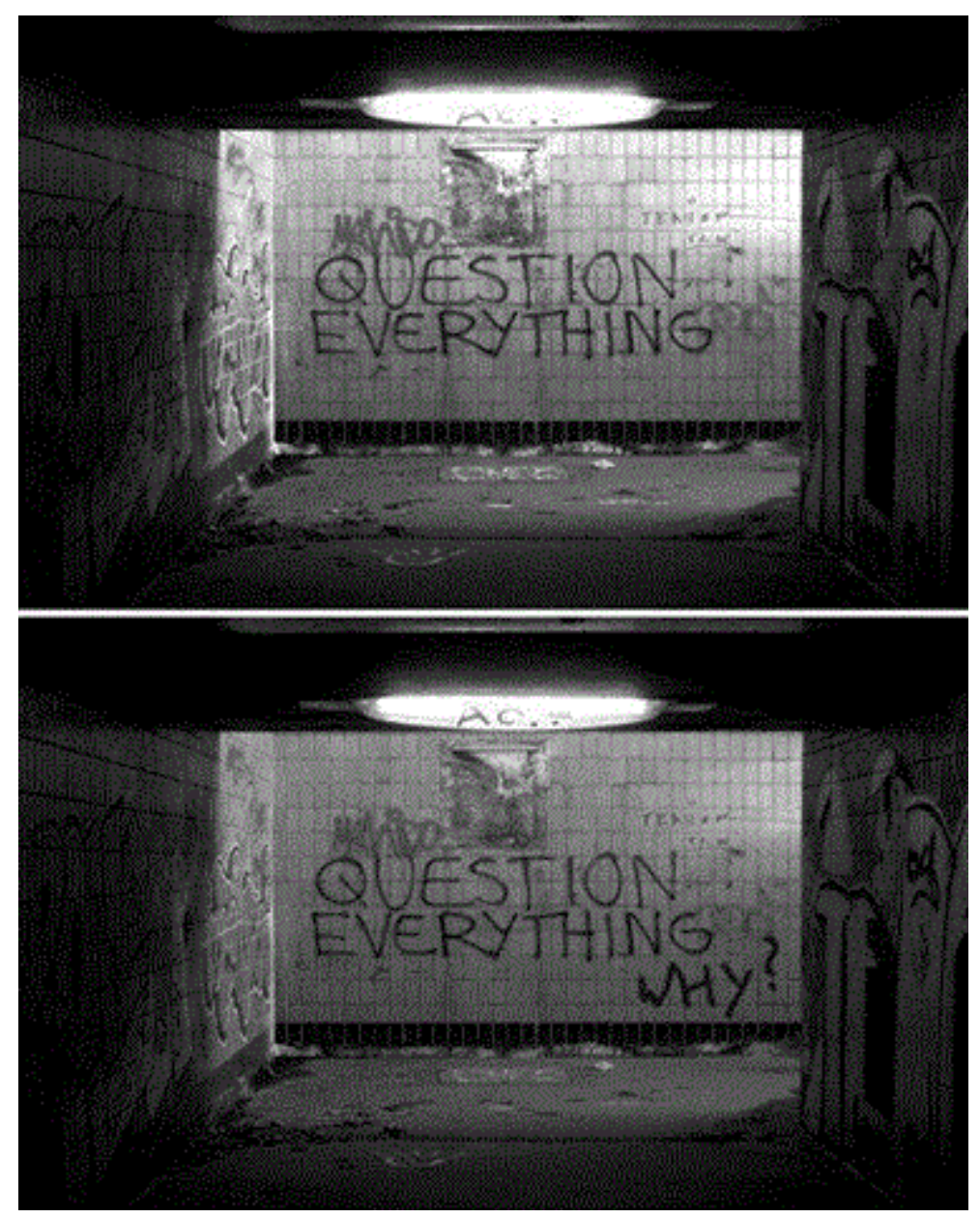

Logo, faz-se necessário esclarecer algumas coisas sobre o que Coutinho chamou de "razão reduzida ao intelecto":

É interessante assinalar, de passagem, que Kierkegaard refere-se a uma "dialética" puramente qualitativa para descrever as passagens das etapas estética, ética e religiosa entre si. Já os estruturalistas, particularmente 


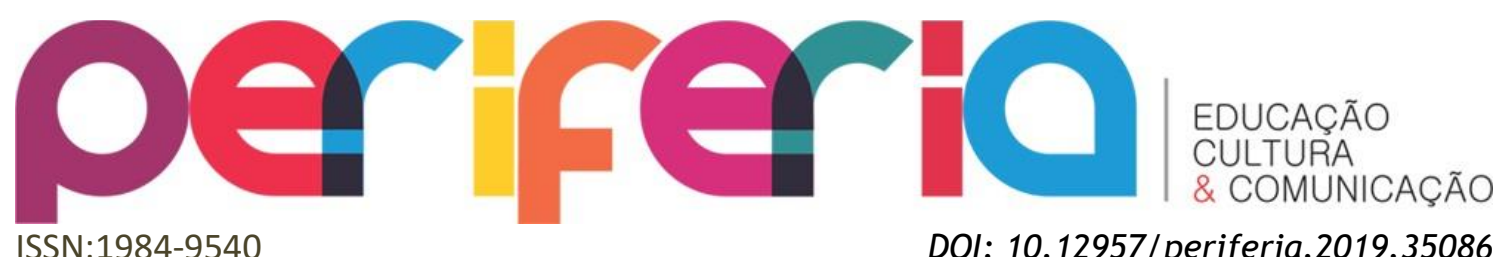

Lévi-Strauss, como veremos, acreditam numa evolução puramente quantitativa, sem alterações de qualidade (ou seja, sem modificações categoriais). Ambas as posições são falsas, na medida em que desconhecem uma das leis básicas da razão dialética, ou seja, a unidade e integração das modificações qualitativas e quantitativas. A transformação de qualidade sem a mediação da quantidade é tão irracional e absurda quanto um crescimento quantitativo sem alterações de qualidade (...). A sociologia positivista e a economia vulgar, por um lado, desligando-se da história e formalizando ao extremo seu objeto, afastam de suas preocupações qualquer referência à objetividade das contradições no capitalismo; a filosofia, por outro lado, transformando-se em pura epistemologia (isto é, recusando cidadania filosófica à ontologia e à ética) (2010, p. 48 e 50-51).

Portanto, eliminar dialética e/ou contradição do trabalho de pesquisa significa retirar desta a maneira de extrair da contradição o conhecimento e/ou fechar-se a uma dimensão da realidade rica de dados e, podemos dizer, parte fundamental do objeto de estudo; contudo, não totalizada enquanto um novo conhecimento. Seguindo esta concepção metodológica, tratamos de analisar a realidade e moldar a proposta de trabalho por meio do holismo implícito nesta proposta, tratando as relações entre quantidade e qualidade, entre abstrato e concreto, entre formal e substantivo sem reducionismos comuns na referida literatura. 0 recurso pedagógico gráfico, especialmente os memes e quadrinhos ocorre porque estes - como forma de arte - não podem se dar ao luxo de realizar este reducionismo, da quantidade sobre a qualidade, por exemplo, pois são peças de arte que devem seguir a constituição "humanamente natural e naturalmente humana" da omnilateralidade, do ser humano totalizado; porque esta arte e as demais dirigem-se diretamente aos sentidos humanos. 


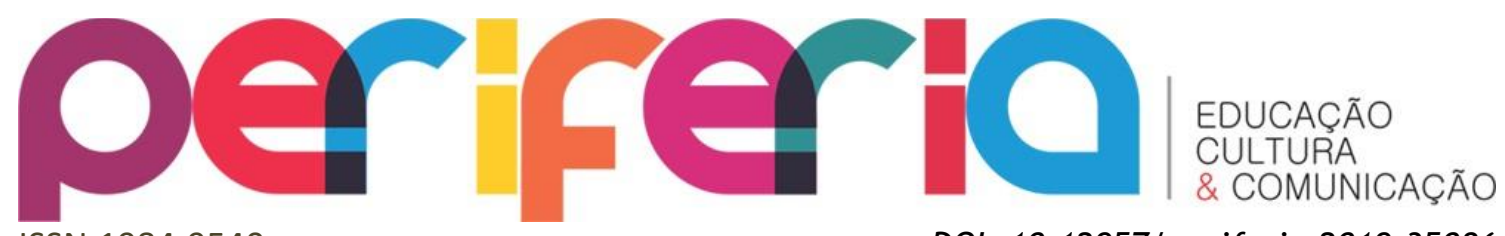

ISSN:1984-9540

DOI: $10.12957 /$ periferia.2019.35086

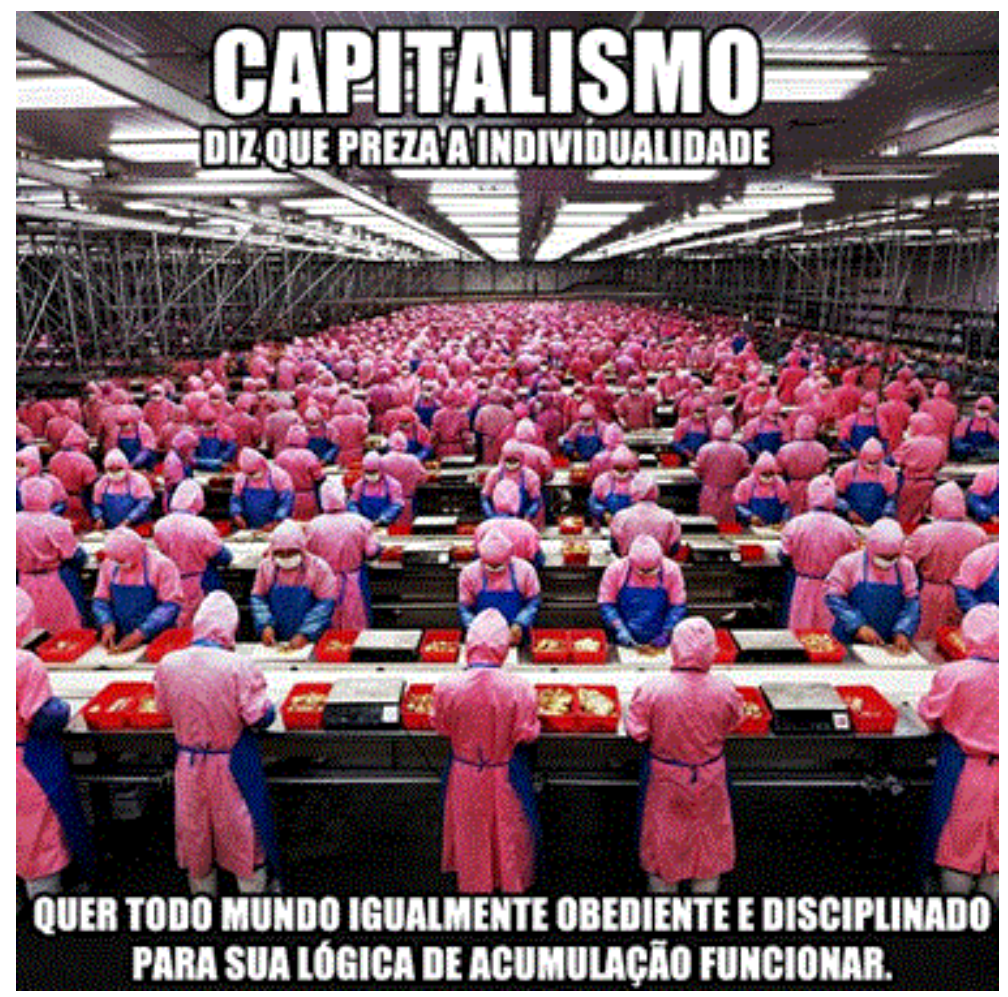

A contradição é tão presente na sociedade do capital que mesmo que ele, de muitas maneiras, limite o desenvolvimento do indivíduo; contudo, foi também o primeiro sistema a realmente desenvolver as capacidades individuais através da divisão do trabalho. 0 capital definitivamente faz as duas coisas, embora Mészáros entenda que ele tem preferido mais igualar destruição a consumo que desenvolver as capacidades humanas individuais - que são uma riqueza econômica também.

Outro equívoco contido nesta questão da diferença entre a razão, a lógica e a dialética que pretendemos evitar é estar preso à ideia de que o conhecimento apenas nasce por meio da lógica em objetos homogêneos e não-contraditórios. Coutinho (op. Cit), comentando a "miséria da razão" do estruturalismo, demonstra a inconsistência ontológica desta forma histórica teórico-metodológica:

O conjunto global da linguagem é incognoscível, já que não é homogêneo". Observa-se aqui um evidente processo de projeção do epistemológico (a abstração de um elemento) no ontológico (a arbitrária transformação desse elemento abstraído em uma entidade fetichizada). Por outro lado, é clara aqui a sujeição de Saussure à "miséria da razão"; para ele, somente o homogêneo, isto é, o não contraditório, é passível de apreensão racional. Nesse ponto, o conceito saussuriano da 


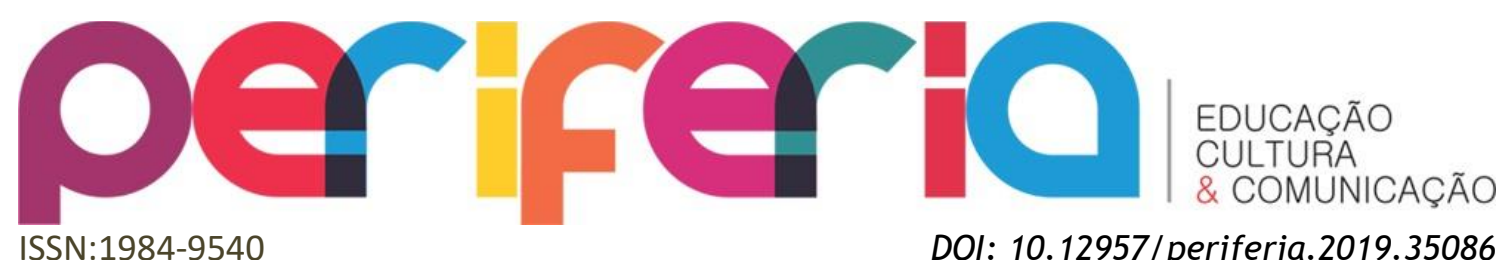

ISSN:1984-9540

razão é diretamente derivado de Comte (...). 0 "inconsciente" é o fetiche das regras intelectivas que são próprias da práxis manipulatória (...). Tanto Lévi-Strauss quanto Foucault afirmam a existência de um nível mental mais profundo, "inconsciente" ou seja, o pensamento e a vida social dos homens concretos. Ambos são agnósticos diante da história: enquanto Lévi-Strauss considera simples "doxologia" - simples opinião subjetiva qualquer afirmação relativa à história real dos homens (...). Desconhecendo a gênese histórico-ontológica dos processos, Lévi-Strauss converte essas regras fixadas pelo hábito e tornadas inconscientes num a priori idealista. (...) Limitando a razão ao intelecto, Sebag destrói a dialética de universal, particular e singular, que permite apreender casualidades singulares (2010, pp. 83, 101, 140, 157).

Uma coisa é dizer que há o inconsciente e as estruturas sociais, o que não negamos; outra é atribuir-lhes este fetichismo. A maneira pela qual a razão analítica trabalha o objeto e o descreve é robótica (não por acaso Coutinho irá relacioná-la à Tecnoestrutura); justo o contrário do caráter orgânico de sociedade e indivíduo social. Além disso, podemos apenas fazer uma análise da estrutura - inconsciente ou não - da língua, concatenando-a aos demais complexos de complexos: trabalho e pensamento. $\mathrm{E}$, embora o meme faça referência a uma situação particular, o conteúdo de Sociologia demonstra como esta situação particular está em unidade com o universal e o singular. 0 caráter complementar destes complexos pode ser literalmente ilustrado.

Mészáros demonstra a importância dessa postura decididamente dialética, que, do contrário, limitando-se a lógica, a persistência, pode comprometer a pesquisa, derrubando mesmo um dialético como Hegel:

O processo de vida concebido dessa forma por Hegel é extremamente problemático na medida em que opera com a ajuda do conceito lógico-metafísico apriorístico da apenas declarada 'mediação' em vez de uma categoria historicamente inteligível e identificável de mediação social (2009, p. 155).

Assim, a mediação deve ser buscada, mas deve-se estar consciente de que ela é uma mediação social - a mediação entre o universo do educando do Estado e o educador. As imagens facilitam muito este trabalho, pois além de sintetizar bastante conteúdo semântico, a imagem ativa os sentidos humanos teoréticos aos quais Marx 


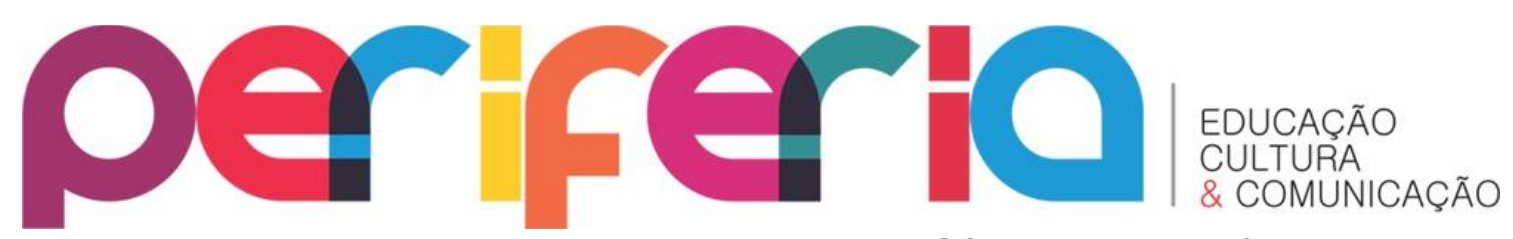

ISSN:1984-9540

DOI: 10.12957/periferia.2019.35086

faz referência nos Manuscritos. Esta questão da mediação social pode parecer truísmo e, talvez, até mesmo tautologia; entretanto é uma coisa com a qual não estamos acostumados, pois nossa socialização se faz no momento em que a "consciência alienada" é o momento predominante, e não a "consciência da alienação". Isso pode ser visto como as "saídas" coletivas dos problemas sociais perderam drasticamente força. 0 capital trata de - por meio da expropriação do trabalho - criar uma série de mediações sociais (que seriam universais, como também o sociometabolismo exige uma mediação social), mas estas são pseudouniversais. Nesta forma societária e igualmente no conceito teórico, é notório como o dualismo e a dicotomia ocorrem: junto à postulação de uma instância coletiva, temos o individualismo - assim, oscila-se entre o estruturalismo e o individualismo metodológico.

E a mediação social realmente viável, em meio à autoalienação, para ser uma mediação bem-sucedida do ser social, deve ser formada pelas estruturas fundamentais ontológicas às quais fizemos referência: $\Theta$ trabalho $\Theta$ linguagem $\boxminus$ pensamento $\Theta$. Evidentemente, apenas lançando mão de procedimentos lógicos e dialéticos é possível chegar a uma mediação social, fazendo como que o meme e a cybercultura ofereçam seus serviços à instituição de uma mediação social por meio da educação, isto é, à capacidade que o ser humano tem de direcionar o trabalho sobre si mesmo e melhorar-se.

Logo, sendo o universo do educando ainda predominantemente marcado pela cultura oral, sendo a imagem um objeto humano no qual estão mediadas muitas ideias, centramos nosso trabalho no uso intensivo dos elementos gráficos, porque a imagem sintetiza bem este complexo de complexo e, algo essencial de seu caráter ontológico, este complexo de complexos - quando o estranhamento do ter não destruiu os sentidos teoréticos - só pode operar em sua complementaridade, esta é a omnilateralidade à qual Marx faz referência, mesmo na indústria alienada. Com esta estratégia pedagógica podemos ter - no material didático - um suporte material para que os educandos se sintam motivados, por meio da aproximação dos dois universos (educando e educador), a direcionar sua capacidade de trabalho sobre si 


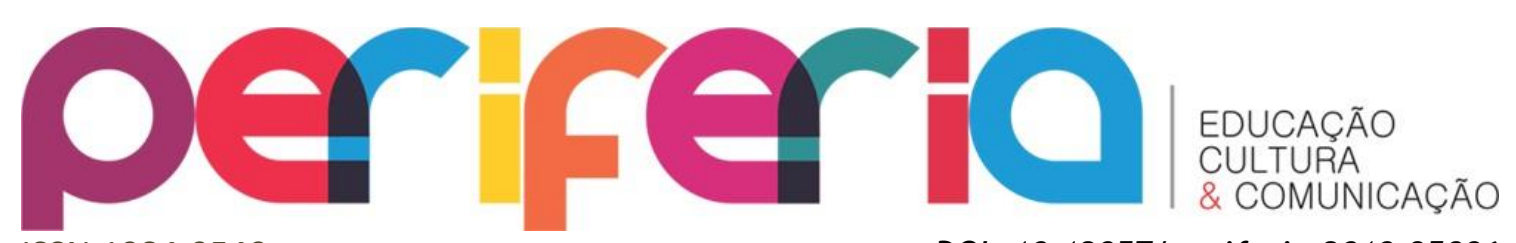

ISSN:1984-9540

DOI: 10.12957/periferia.2019.35086

mesmos, descobrindo, desta maneira, aos poucos, a riqueza dos seus sentidos teoréticos e do conteúdo de Sociologia.

Contudo, se este é um material didático adequado ao Ensino-aprendizagem, demanda também uma maneira adequada para trabalhá-lo em sala de aula. Mesmo com elementos gráficos, ouvindo e falando a linguagem dos educandos, é necessário ainda que a postura do educador que esteja em sintonia com a exposição que fizemos acerca dos objetivos e parte teórica. É preciso levar em consideração as descobertas que os educandos já fizeram, avaliá-los segundo o que eles objetivaram (seja em trabalho, seja em palavra) e até onde seus sentidos foram cultivados. Vejamos melhor esta questão.

Devido ao fato de estar inserido na concepção filosófica que compreende que o singular e o particular não estão em unidade com o universal ou por sequer saber lidar com estes conceitos, o educando, muitas vezes, imagina que as situações trazidas pelos memes são situações particulares que não dizem respeito a mais nada se não àquilo a que o meme faça referência. Não entendendo que entre singular, particular e universal há mediações que os mantêm em unidade, o educando não consegue enxergar que, como no fio condutor do enredo do meme existem as estruturas sociais que criam a situação que constitui o argumento da peça. 0 objetivo de nossa aula é que o educando consiga não apenas entender o quadrinho como também entender a estrutura social que condiciona a ação. 0 professor deve sempre explicitar a relação entre os dois - estrutura social e enredo - de maneira clara e com linguagem acessível, inclusive citando exemplos diferentes.

Além disso, o educando (com sua cultura marcadamente oral) não está habituado a uma linguagem mais complexa que, frequentemente, há nos memes. Dessa forma, o conteúdo deve ser explicitado, sem deixar de adicionar novos elementos do vocabulário ao repertório do educando. Outras dificuldades que encontramos é o uso de conceitos e figuras de linguagem com os quais o educando não está habituado. Mas, nada que uma explanação acerca do conceito e seu sentido - lembrando sempre que este não é um pensamento na cabeça dos cientistas sociais, mas também uma realidade material da forma de ser - levando o educando à 


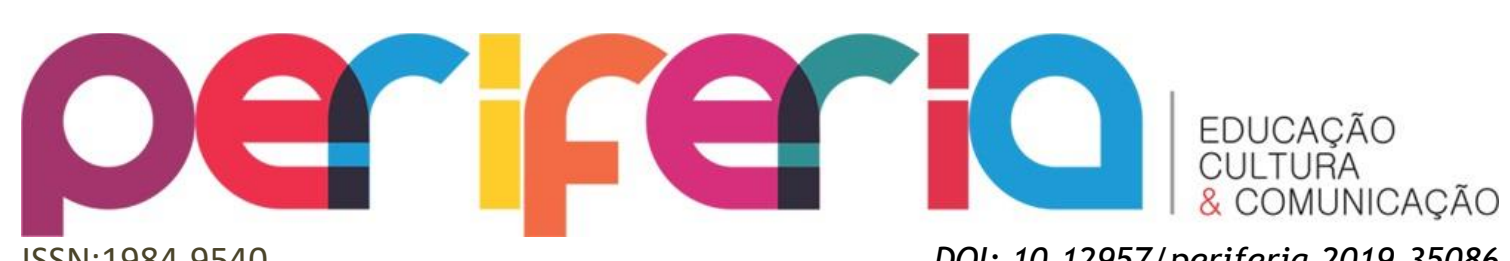

ISSN:1984-9540

DOI: 10.12957/periferia.2019.35086

compreensão do conceito e o seu uso no enredo. Por sua vez, deve-se também explicar as figuras de linguagem presentes (ironia, hipérbole, metonímia, metáfora, etc.), o que não é tarefa impossível, pois mesmo que não conheçam o significado destas palavras, com certeza já fazem uso corrente destas figuras de linguagem na comunicação usual.

No exemplo, a igualdade burguesa pode ser apresentada com uma simples imagem. A igualdade política e legal deixa de se efetivar porque é fundada em uma total desigualdade ontológica e econômica. Pode-se lembrar que nos regimes anteriores, pré-capitalistas, a "igualdade" é ainda mais restrita. Esta figura também mostra como o Estado está ligado invariavelmente à classe dominante.

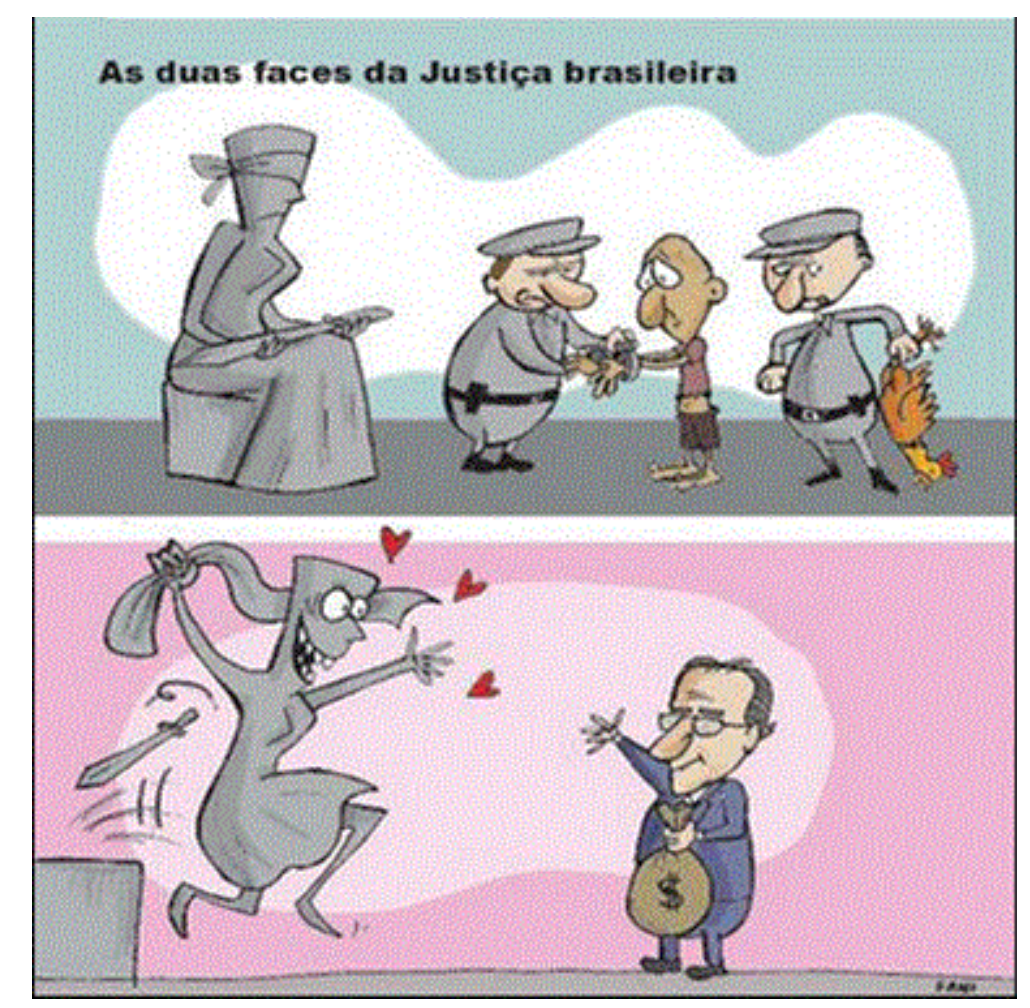

Outro obstáculo que pode ocorrer na compreensão do material gráfico é o desconhecimento de fatos históricos e sociais que sejam citados nos memes, mas pela maneira como estes elementos gráficos transmitem seu argumento - cheia de significado e usando imagens fortes - vemos que, uma vez que educador exponha os fatos históricos e sociais, os educandos não encontram tantas dificuldades em compreender a ilustração e a relação entre sua realidade - ou entre a ilustração e o 


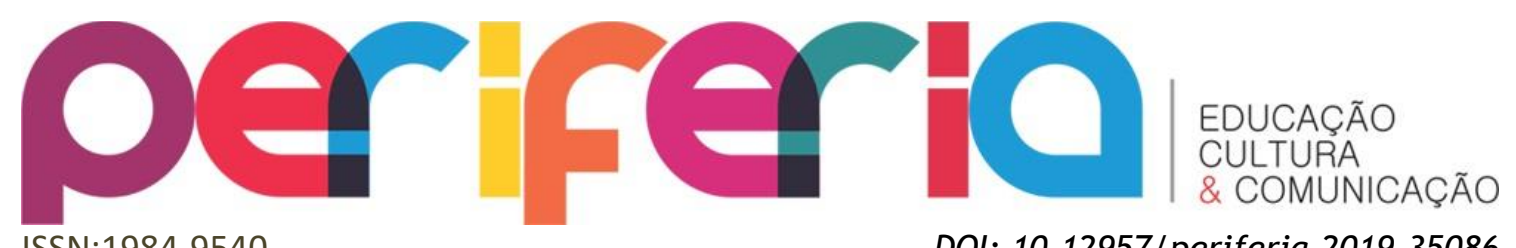

ISSN:1984-9540

DOI: 10.12957/periferia.2019.35086

conteúdo de Sociologia. Por último, o senso comum trazido pelo educando é um obstáculo, mas a concretude com a qual o meme ilustra o discurso abstrato em uma situação social retratada por ele ajuda muito a ultrapassar o senso comum. Atentamos em nosso trabalho para o fato de ser menos a explicação oferecida pelo senso comum que o valor emotivo que ela possui para o educando a principal fonte de resistência a um diálogo com o conteúdo de Sociologia. Mas, sempre que forem trabalhadas estas emoções é comprovado, por parte do educador, como todos possuem capacidade de se contraporem ao enorme peso das estruturas sociais porque são indivíduos sociais automediadores - esta resistência do senso comum tende a ceder.

\section{REFERÊNCIAS}

BOURDIEU, P. (2002). Escritos de Educação. Petrópolis: Editora Vozes.

COUTINHO, C. (2010). O Estruturalismo e a miséria da Razão. São Paulo: Expressão Popular.

DEBORD, G. (2011). A sociedade do espetáculo - Comentários sobre a sociedade do espetáculo. Rio de Janeiro: Contraponto.

LESSA, S. (2006). Curso: trabalho e sujeito revolucionário no debate contemporâneo, disponível em http://sergiolessa.com/, acessado em 21 junho de 2010.

HOLZ, H.; ABENDROTH, L. (1969). Conversando com Lukács. Rio de Janeiro: Editora Paz e Terra.

MARX, K. (1994). O capital - crítica da Economia política. Livro 1, Volume 2. Rio de Janeiro: Editora Bertrand.

. (2004). Manuscritos econômico-filosóficos. São Paulo: Boitempo Editorial.

MOTA, K. C. C. da S. (2003). Os lugares da Sociologia na educação escolar de jovens do Ensino Médio: formação ou exclusão da cidadania e da crítica?

Dissertação apresentada como requisito parcial à obtenção do título de Mestre em Educação Universidade do Vale do Rio dos Sinos - Unisinos.

MÉSZÁROS, I. (2006a). A teoria da alienação em Marx. São Paulo: Boitempo Editorial. 


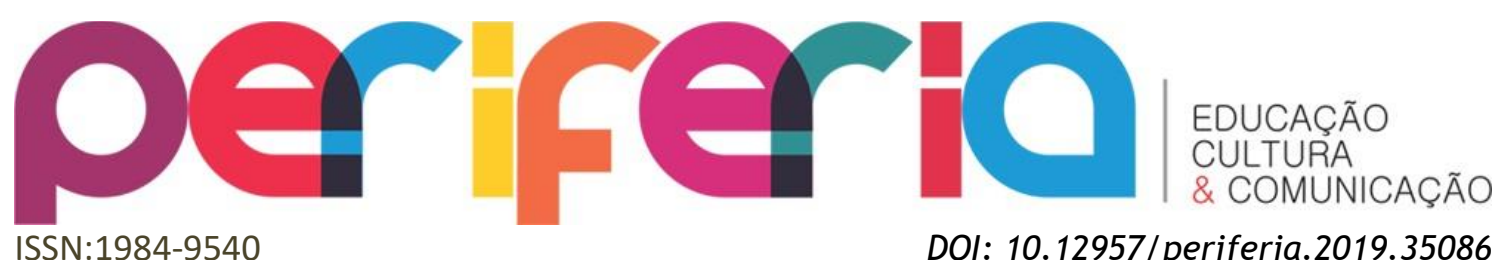

. (2006b). Para além do capital - Rumo a uma teoria da transição. São Paulo: Boitempo Editorial.

- (2009). Estrutura social e formas de consciência - A determinação Social do método. São Paulo: Boitempo Editorial. . (2011). Estrutura social e formas de consciência II - A dialética da estrutura e da história. São Paulo: Boitempo Editorial. 